\title{
On The Future Of Energy And Resource Security in The United Arab Emirates: SWOT Analysis And Problem Solving
}

\author{
Fares M. Howari, Yousef Nazzal, Ahmad Yousef,
}

\begin{abstract}
The United Arab Emirates is making notable progress in diversifying its economy through tourism, trade, and manufacturing. However, in the near term, oil, natural gas, and associated industries will continue to account for the majority of economic activity. Rising gas demand from power stations and industrial users such as petrochemical producers and steel manufacturers has turned the UAE into a net gas importer in the past decade, triggering multi-billion dollar investments into nuclear power and renewable energy. This paper looks into the patterns of energy production and consumption in the UAE in the context the changing nature of global energy markets. The paper analyzes current and proposed national energy initiatives, and assesses their impacts on the future of the country. The research considers a wide range of statistics from various sources to highlight the current situation and to predict future scenarios. The study also includes a SWOT analysis of the energy situation in the UAE and examines the impact of external factors. The demand for electricity in the UAE, which is almost exclusively generated from natural gas-fired power plants, is expected to rise at a rate of about 9 percent per annum through 2020 .
\end{abstract}

Keywords-Energy, resource security, UAE, SWOT analysis.

\section{Introduction}

The United Arab Emirates (UAE), a federation of the seven emirates of Abu Dhabi, Ajman, Al Fujayrah, Dubai, Ras al Khaymah, Sharjah, and Umm al Qaywayn (Figure 1), relies on its vast oil and natural gas resources to sustain its economy. Together with the hydrocarbon economy, the UAE is evolving as one of the world's significant financial centers and a major trading hub in the Middle East. The UAE investments in infrastructure and technology support the UAE's economy, and International Monetary Fund (data indicate that the UAE GDP grew by $4.3 \%$ in 2012, and the trend continues to be healthy at the moment.

Fares M. Howari

College of Natural \& Health Sciences, Zayed University United Arab Emirates

Yousef Nazzal

Corresponding author

College of Natural \& Health Sciences, Zayed University

United Arab Emirates

Ahmad Yousef

Ministry of Energy \& Industry

United Arab Emirates
In many countries renewable energy already has a significant market share. The use of renewable energy has developed along different lines in different countries. Many studies have examined energy resources in various parts of the world, including those of Foley et al. (2010) [6], Dassisti and Carnimeo (2012) [3], and Lipp (2007) [8], and Brennan et al. (1996). The UAE, which is the second largest Arab economy, also has energy options and is developing plans, initiatives and strategies to create a diversified and efficient energy portfolio by including unconventional resources that will sustain future economic growth and extend the country's position as a reliable supplier of crude oil to global markets (United Arab Emirates (UAE) State of Energy Report, 2015) [18]. The present paper describes and analyzes those options and strategies in the context of the mixed news of alternating low hydrocarbon in the global market. For economic growth in the UAE, unconventional energy sources are important and are expected to affect future economic development and growth. In this paper, we describe the role of unconventional and renewable energy sources in the planed future energy mix of the UAE. Taking into account the global conventional energy market, a SWOT (strengths, weaknesses, opportunities, and threats) analysis of the energy sector at the current juncture is undertaken as it can provide useful insights.

The main objective from this study is to assess the current status, and examine the future energy mix in the UAE, utilizing a SWOT analysis and other information and insights. The utilization of a SWOTs analysis is important because it can provide advice on planning and steps to achieve goals [6]. Often, it is useful for decision makers to evaluate an objective and its attainability via a SWOT. When an objective is deemed not attainable, then a different objective should be decided on and the process repeated. Users of SWOT analysis need to ask and answer questions that generate meaningful information on strengths, weaknesses, opportunities, and threats to make the analysis useful and find competitive advantages (Nadine and Richter 2009; Terrados et al. 2007 [17]). According to Cherni, J., Kentish, J. (2007) [2].. According to Thomas , et al., 2007 [16] the strengths, weaknesses, opportunities, and threats involved in a project or in a business venture can be ascertained well with a SWOT analysis. 


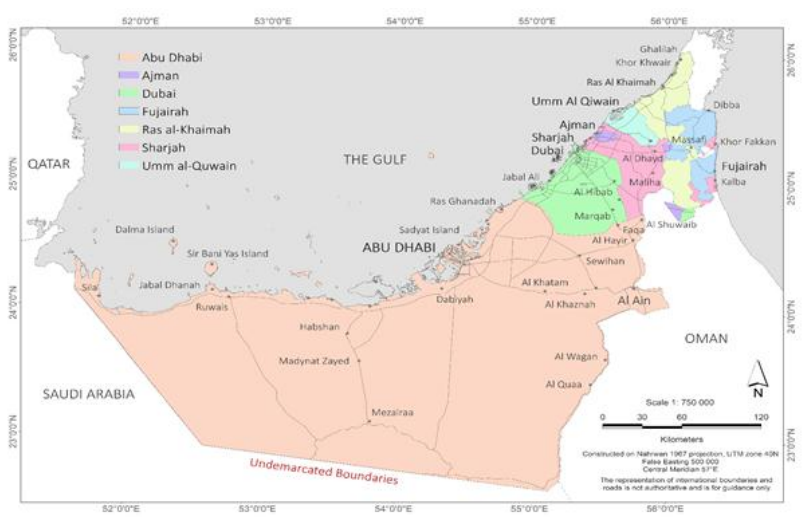

Figure 1. Map showing the UAE location

\section{Methodology}

A literature review is utilized, since it is the most effective way of gathering information in this kind of study. The same methodology was used in similar past studies. Lewis and Wier (2007) [9] used a literature review methodology to examine the vital roles of national and subnational policies in providing the support needed to develop successful wind turbine manufacturing companies. Cherni and Kentish (2007) [2] examined the effectiveness of the renewable energy policy and legislation implemented in China. Mitchell and Connor (2004) [10] examined the renewable energy policy in the UK between 1990 and 2003. SWOT analyses have also used in studies similar to the one reported here, e.g., by Iglinski et al. (2015) [7]. Applying these approaches (analysis of literature, statistics and analytics) to the current research required extensive analysis of the policies currently employed in UAE, especially in the preparation of the SWOT status.

The SWOT analysis to UAE was conducted using the information provided by the Ministry of Energy (MOENR), data from literature sources, the strategy for the development of renewable energy sources as well as legal acts and regulations. Recommendations on how to develop a particular renewable energy sector have more quickly been incorporated.

\section{Methodology}

\section{A. Status of Fossil Fuels in the UAE}

Figures 4, 5, and 6 shows the crude oil proven reserve, demands and exports for the UAE also Table 1 shows Summary of energy statistics for the UAE. The data's shows pressure on the UAE's fossil fuel resources comes from local internal demands and from the desire to meet international commitments of OPEC. Oil reserves in the United Arab Emirates are about 98 billion barrels (15.6×109 m3). Among the Emirates oil with 92 billion barrels $(14.6 \times 109 \mathrm{~m} 3)$, most is in Abu Dhabi which has 4 billion barrels $(640 \times 106 \mathrm{~m} 3)$ and Sharjah which has 1.5 billion barrels $(240 \times 106 \mathrm{~m} 3)$. Most of the oil is in the Zakum field, which is the third largest in the Middle East and which has an estimated 66 billion barrels $(10.5 \times 109 \mathrm{~m} 3)$ of oil. The UAE produces about 2.9 million barrels per day $(460 \times 103$ $\mathrm{m}^{3} / \mathrm{d}$ ) of total oil liquids, and more than 5 million barrels per day $(790 \times 103 \mathrm{~m} 3 / \mathrm{d})$ by 2016 . The UAE's reserves-toproduction ratio is about 93 years (Table 2), (Figures. 4, 5 and 6). The likelihood of further major oil discoveries is low, but the UAE uses enhanced oil recovery (EOR) techniques to increase the extraction rates of the country's mature oil fields. Higher oil prices will help increase the commercial viability of EOR (United Arab Emirates (UAE) State of Energy Report, 2015) [18]. June got the highest crude oil production from the different sources (Figure 7).

Natural gas use in the UAE is rising. While the country is a member of the Gas Exporting Countries Forum (GECF), domestic demand is likely to draw heavily on the UAE's potentially-exportable natural gas resources. Presently, the country both imports and exports liquefied natural gas (LNG) and shares international natural gas pipelines with Qatar and Oman. The UAE is also one of the world's leaders in the use of natural gas in EOR techniques, but with natural gas demand rising, the government plans to expand into other EOR techniques to divert the gas volumes for domestic consumption US Energy Information Administration (2014) [21]. The United Arab Emirates was the first country in the Middle East to export liquefied natural gas (LNG), and has exported more than 250 billion cubic feet of LNG annually, almost exclusively to Asia. Despite steadily increasing production, the UAE became a net importer of natural gas in 2008. Consumption in the UAE grew by an average of more than $5 \%$ per year between 2003 and 2012, which was only partially met by domestic production, US Energy Information Administration (2014) [21]. The United Arab Emirates plans to boost domestic natural gas production over the next several years to help meet growing internal demand. Much of the growth could come from the country's large sour (high sulfur) gas deposits.

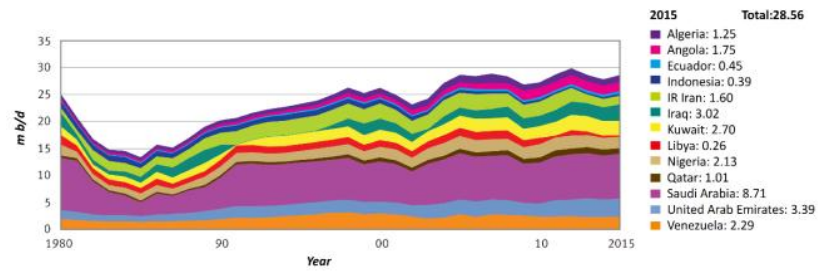

Figure 2. OPEC members exports of crude oil and petroleum products

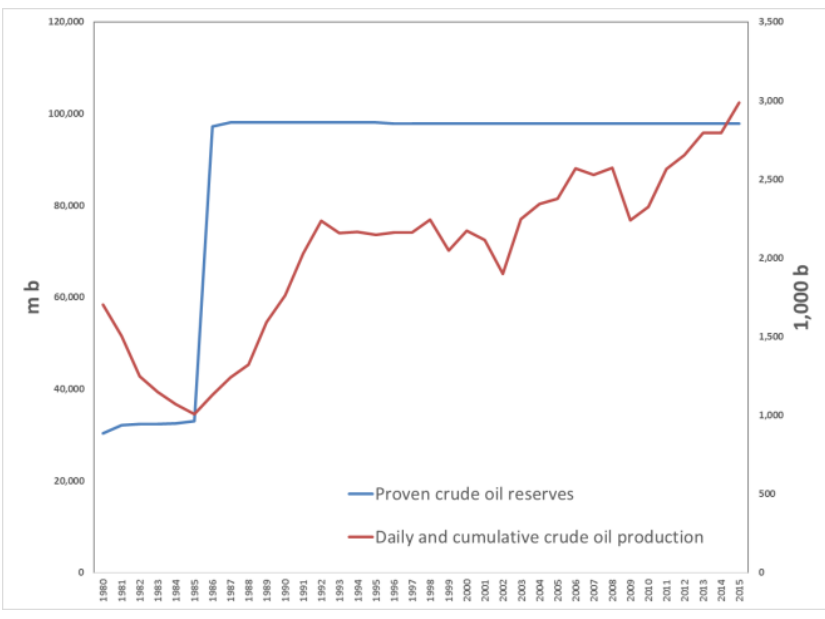

Figure 3. Proven crude oil reserve and production in UAE 


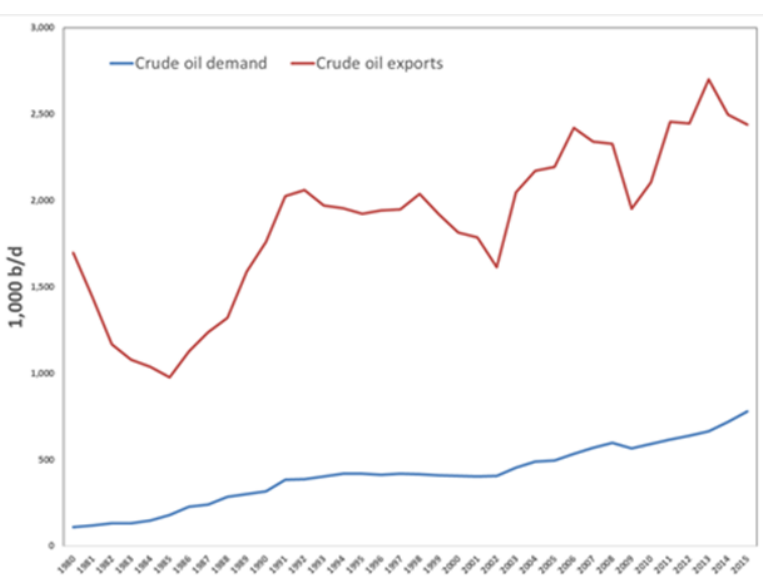

Figure 4. Shows the crude oil demand and exports in UAE

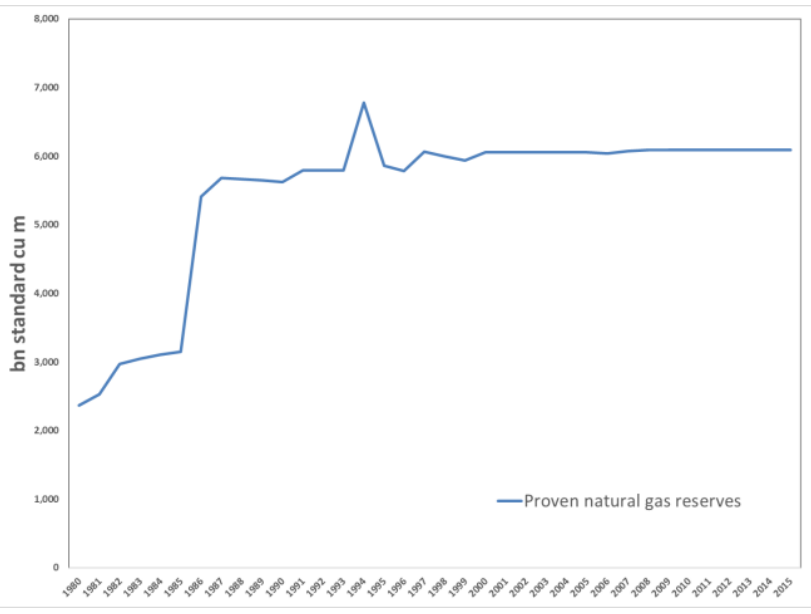

Figure 5. Proven natural gas reserves in UAE

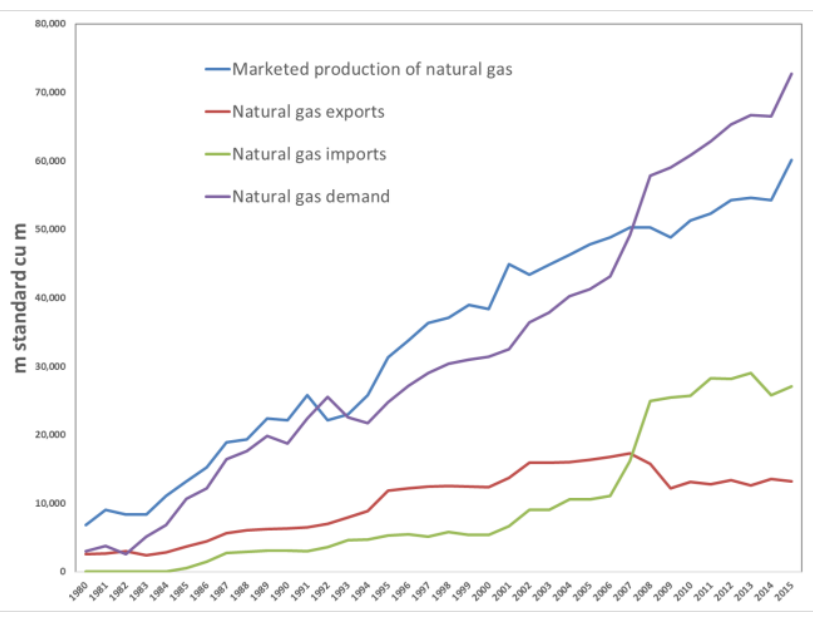

Figure 6. Shows the NG production, demand, exports and imports in UAE.

The UAE holds the seventh-largest proved reserves of natural gas in the world, at just over 215 trillion cubic feet (Tcf) (Figure 2) . Despite its large endowment, the UAE became a net importer of natural gas in 2008- 2015 (Figure 3 ) . This phenomenon is a product of two things: (1) the UAE reinjected approximately $26 \%$ of gross natural gas production from 2003 to 2012 into its oil fields as part of EOR techniques, and (2) the country's inefficient and rapidly-expanding electricity grid already taxed by the swift economic and demographic growth of recent decades relies on electricity from natural gas-fired facilities.

To help meet the growing demand for natural gas, the UAE boosted imports from neighboring Qatar via the Dolphin Gas Project's pipeline over the past several years. The pipeline runs from Qatar to Oman via the UAE and is one of the principal points of entry for the UAE's natural gas imports. In addition to the imports from Qatar, Dubai and Abu Dhabi both engage in LNG trading; the former as an importer and the latter as an exporter. The UAE is a member of the Gas Exporting Countries Forum (GECF).

The UAE's natural gas has a relatively high sulfur content that makes it highly corrosive and difficult to process. For decades, the country simply flared the gas from its oil fields rather than undertake the extensive and expensive processes associated with separating the sulfur from the gas. The technical difficulties of producing the country's sulfur-rich (sour) gas once posed a great impediment to the development of the UAE's reserves, but advances in technology and the growing domestic demand for natural gas make the country's vast reserves an enticing alternative to Qatari imports. (Table 2).

\section{B. Energy Consumption as Electricity}

The UAE is witnessing unprecedented socio-economic growth which puts pressure on the available energy resources. The rapid economic growth and the increase in population have led to an annual increase in the consumption of electricity of $6 \%$, which is large compared to the average global growth rate. $35 \%$ of electricity consumption is attributable to the residential sector and about $31 \%$ to the commercial sector, making these two sectors the largest energy consumer in the country. The annual increase in the cost of electricity for the UAE is typically 35 billion dirhams,

Most of the UAE's electricity is generated using gas-fed thermal generation, and plans to integrate the seven Emirates' gas distribution networks (for example, through the Dolphin Pipeline project) should help alleviate some of the peak-demand shortfalls experienced in the past. These challenges are worsened by subsidy programs that keep domestic prices artificially low, and contribute to wasteful energy practices. Privatization of the electricity sectors in the seven Emirates is possible but not formally planned at this time, according to the Federal Competitiveness and statistics Authority 2016

Another complicating factor is that UAE has one of the highest rates of per capita petroleum consumption in the world. The UAE is both a major exporter and consumer of petroleum and petroleum products. The U.S. Energy Information Administration (EIA) estimates that the UAE exported more than 2.5 million bbl/d of crude oil in 2012, the great majority to Asian markets. Although the UAE is a major global petroleum exporter, its domestic market relies heavily on petroleum and petroleum products to satisfy energy demands. Most of the UAE's petroleum imports are of residual fuel oil, with limited imports of motor gasoline and diesel fuel. In 2012, the UAE had the seventh-highest per capita petroleum consumption in the world, consuming nearly $620,000 \mathrm{bbl} / \mathrm{d}$ based on the (Middle East Economic Survey, 2014 [11]) (Figure 7). 
Proc. of the Sixth Intl. Conf. Advances in Bio-Informatics, Bio-Technology and Environmental Engineering- ABBE 2018 Copyright (C) Institute of Research Engineers and Doctors, USA .All rights reserved.

ISBN: 978-1-63248-148-1 doi: 10.15224/978-1-63248-148-1-10

TABLE I. SUMMARY OF ENERGY STATISTICS FOR THE UAE

\begin{tabular}{|c|c|c|c|}
\hline \multicolumn{4}{|c|}{ Oil } \\
\hline $\begin{array}{c}\text { Proven reserves, } \\
2013 \text { (million } \\
\text { barrels) }\end{array}$ & $\begin{array}{c}\text { Total oil } \\
\text { supply, 2012 } \\
\text { (thousand } \\
\text { bbl/d) }\end{array}$ & $\begin{array}{l}\text { Total petroleum } \\
\text { consumption, } \\
2012 \text { (million } \\
\text { barrels) }\end{array}$ & $\begin{array}{l}\text { Reserves-to- } \\
\text { production } \\
\text { ratio }\end{array}$ \\
\hline 97,800 & 3,213 & 618 & 95 \\
\hline \multicolumn{4}{|c|}{ Natural gas } \\
\hline $\begin{array}{c}\text { Proven reserves, } \\
2013 \text { (billion } \\
\text { cubic feet) }\end{array}$ & $\begin{array}{c}\text { Dry natural gas } \\
\text { production, } \\
2012 \text { (billion } \\
\text { cubic feet) }\end{array}$ & $\begin{array}{l}\text { Dry natural gas } \\
\text { consumption, } \\
2012 \text { (billion } \\
\text { cubic feet) }\end{array}$ & $\begin{array}{l}\text { Reserves-to- } \\
\text { production } \\
\text { ratio }\end{array}$ \\
\hline 215,025 & 1,854 & 2,235 & 116 \\
\hline \multicolumn{4}{|c|}{ Electricity } \\
\hline $\begin{array}{c}\text { Generating } \\
\text { capacity, } \\
2011 \\
(G W)\end{array}$ & $\begin{array}{c}\text { Electricity } \\
\text { generation, } \\
2011 \\
\text { (billion } \mathbf{k W h} \text { ) }\end{array}$ & $\begin{array}{c}\text { Electricity } \\
\text { consumption, } \\
2011 \\
\text { (billion } k W h \text { ) }\end{array}$ & $\begin{array}{c}\text { Distribution } \\
\text { losses, } \\
2011 \\
\text { (billion } k W h \text { ) }\end{array}$ \\
\hline 26.1 & 97.9 & 82.5 & 7.2 \\
\hline
\end{tabular}

Source: U.S. Energy Information Administration (2014)

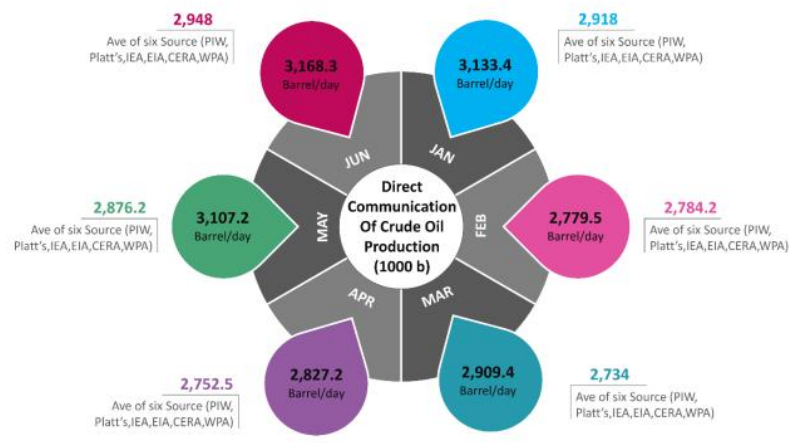

Figure 7. Comparison with average to crude oil production from different sources 2016.

The United Arab Emirates plans to boost domestic natural gas production over the next several years to help meet growing internal demand. Much of the growth could come from the country's large sour (high sulfur) gas deposits (Figure 8). The UAE holds the seventh-largest proven reserves of natural gas in the world, at just over 215 trillion cubic feet (Table 2). In 2008, the UAE become a net importer of natural gas despite its large endowment. This occurred for two reasons: (1) the UAE re-injected approximately $26 \%$ of gross natural gas production from 2003 to 2012 into its oil fields as part of EOR techniques (Figures 2 and 3) the country's inefficient and rapidlyexpanding electricity grid, already stressed by the rapid economic and demographic growth of recent decades, relies on electricity from natural gas-fired facilities (BP Statistical Review of World Energy, 2014).

\section{Strategies to Meet Internal and External Energy Demands}

Reports indicated that, UAE crude oil production was 3 million barrel per day by 2013, and expected to be 3.5 million barrel per day by 2017 . With this spending came some management actions which were taken and are described in subsequent sections.

\section{1) Strategies and initiatives for fossil fuels}

With limited prospects for major discoveries, the use of EOR techniques in Abu Dhabi oil fields can help increasing the oil production exclusively, according to Middle East Economic Survey (April 11, 2014). One region that may help the UAE boost production is the Zakum petroleum system, which Information Handling Services Company reports may contain over 65 billion barrels of recoverable oil. ZADCO, owned by ADNOC (60\% share), ExxonMobil (28\%), and the Japan Oil Development Company (JODCO) (12\%), manages production from UAE's Upper Zakum field, which currently produces about $550,000 \mathrm{bbl} / \mathrm{d}$ DNOC the Supreme Petroleum Council approved its five-year plan, including expansion of Adco and its offshore oilfields to 3.5 million barrels per day by 2018 from 3.1 million bpd currently. Adco is expected to raise output to 1.8 million bpd from 1.6 million bpd when the expansion plan began. Production from the Lower Zakum field, operated by the Abu Dhabi Marine Operating Company (ADMA-OPCO), should also increase, with production eventually reaching $425,000 \mathrm{bbl} / \mathrm{d}$, compared to the $300,000 \mathrm{bbl} / \mathrm{d}$ it currently produces, according to Middle East Economic Survey, (2015).

ADCO, which oversees onshore operations in the Emirate plans to increase production in the $\mathrm{Bu}$ Hasa, Bab, and SAS fields over the coming years $\mathrm{Bu}$ Hasa Asset contribute $34 \%$ of ADCO's daily oil production. The asset covers an extensive area of 600 square kilometers and includes three fields:Bu Hasa, Huwaila, Bida Al Qemzan. The major field is Bu Hasa which contributes $96 \%$ of the daily asset's oil production, followed by Huwaila that is located $37 \mathrm{~km}$ south of Bu Hasa Field and Bida Al-Qemzan (BQ) which is located $32 \mathrm{~km}$ north of Bu Hasa, contributing $2 \%$ of the daily asset's oil production.

Smaller offshore fields like the Nasr, Umm Lulu, and Umm Shaif are also receiving increased investments. ADMA-OPCO is seeking to boost production levels at the Umm Shaif field to $280,000 \mathrm{bbl} / \mathrm{d}$ and is attempting to bring the combined production of the Nasr and Umm Lulu fields up to $170,000 \mathrm{bbl} / \mathrm{d}$ as soon as 2018. In June 2013, ADMAOPCO awarded a contract for full field development at the Umm Lulu field. ADMA-OPCO also hopes to significantly increase recovery rates at its fields, where the average rate is currently around 35\%, according to industry sources. Exploration and production in the other Emirates is limited, with reserves nearly exhausted and the cost of recovery continuing to climb (Table 2).

Figure 8 shows comparison with average to crude oil production from different sources in 2016. The UAE has decided to invest in raising its production capacity to 3.5 million barrels of oil a day by 2017. The future of energy and resource security in the United Arab Emirates led to the goal that energy production in the form of oil from local refineries will rise from 707 thousand barrels per day to 1.00 million bpd during 2017, and the strategic outlook of the country was to maintain its position as one of the largest petroleum exporting countries in the world. The UAE is advancing in the oil industry field and its global role and weight in the Organization of Petroleum Exporting Countries (OPEC) is strong, noting that the country has $4 \%$ of global oil reserves and about $3.5 \%$ of global gas reserves, according to Facts Global Energy, (2014). 
Table 2: Top 10 countries in terms of proven natural gas reserves, 2013

\begin{tabular}{|l|l|}
\hline \multicolumn{1}{|c|}{ Country } & \multicolumn{1}{|c|}{$\begin{array}{c}\text { Proven natural gas reserves } \\
\text { (trillion cubic feet) }\end{array}$} \\
\hline Russia & 1,688 \\
\hline Iran & 1,187 \\
\hline Qatar & 890 \\
\hline United States & $334^{*}$ \\
\hline Saudi Arabia & 288 \\
\hline Turkmenistan & 265 \\
\hline United Arab Emirates & 215 \\
\hline Venezuela & 195 \\
\hline Nigeria & 182 \\
\hline Algeria & 159 \\
\hline
\end{tabular}

Source: U.S. Energy Information Administration (2013)

\section{2) Strategies and initiatives for unconventional energy sources}

The UAE has access to reasonable renewable energy resources, with an average vertical solar irradiance of 2120 $\mathrm{kWh} / \mathrm{m} 2 /$ year and an average monthly wind speed of $4.2-$ $5.3 \mathrm{~m} / \mathrm{s}$ in coastal areas. The UAE is also has made commitments to the global carbon agenda and has planned to reduce its $\mathrm{CO} 2$ emissions by $30 \%$ by 2030 from the present. With the above drivers, the country announced it aims to attract AED367b (€77.45b) of investment in alternative and sustainable energy projects by 2020 . Both Abu Dhabi and Dubai are targeting the generation of $7 \%$ and $5 \%$ respectively of total electrical power demand from renewable sources by 2030 (Nadine \& Richter ,2009 [13])

According to United Arab Emirates (UAE) State of Energy Report (2015), electrical power generation in the UAE will increase by more than 1.5 gigawatts in $2017 / 18$, enough to power around 150,000 homes. The United Arab Emirates (UAE) State of Energy Report (2015), prepared by the Dubai Carbon Centre of Excellence and the United Nations, highlights energy projects across the UAE focusing on energy diversification and government policy. The report indicates that the UAE aims to increase power generation with a mix of energy sources from natural gas, solar and nuclear energy. From 2008 to 2012, national electrical power demand grew 37 per cent, and that increasing trend has continued to 2017. Abu Dhabi increased its powergenerating capacity by 43.6 per cent and Dubai by 44.5 per cent. The UAE's energy demand is growing at about 9 per cent annually.

Nuclear: In 2009, the UAE awarded a \$20 billion contract to the Korea Electric Power Corporation (KEPCO) to construct four nuclear reactors, and in 2012 the licenses were approved for KEPCO to begin construction on the first two 1,400-megawatt reactors. The first reactor is scheduled to come on-line in 2017, with the others expected to be completed by 2020 . Upon completion of the first reactor, the UAE will become the second country in the region (after Iran) to have a domestic nuclear program. The site is located 300 kilometres west of Abu Dhabi. The UAE expects the second unit to follow in 2018 and units three and four are to come online in 2019 and 2020, respectively, (United Arab Emirates State of Energy Report , 2015).

Solar and wind: The UAE announced plans to develop the Sir Bani Yas wind farm,with a target capacity of 28.8 megawatts, and the Shams 1 concentrated solar power (CSP) plant (100 MW capacity) over the next several years. These are expected to help the UAE diversify its energy mix, according to the Federal Competitiveness and Statistics Authority (2016). Dubai has other major clean energy projects that are expected to feed electricity to the grid in the near future. The second phase in the Mohamed bin Rashid Al Maktoum Solar Park will generate 100 megawatts of solar photovoltaic (PV) power, (United Arab Emirates State of Energy Report ,2015).

Geothermal: Masdar City in UAE is proposing to build the Gulf's first geothermal energy facility. The US\$11 billion project will be partially built by the Icelandic company Reykjavik Geothermal. The company has also been awarded a US\$1.6 million contract to export its geothermal know-how to Masdar City. When complete, the geothermal project will be used to power the city's $5 \mathrm{MW}$ air conditioning system, (United Arab Emirates State of Energy Report ,2015).

Hydrogen Power Abu Dhabi (HPAD): HPAD is a 60/40 joint venture between Masdar and BP to construct the world's first commercial-scale hydrogen-fueled power plant utilizing fossil fuel feedstock and CCS. The project will require a total capital investment (excluding $\mathrm{CO} 2$ transportation and storage) of about AED 7 billion (US\$2 billion). This project will take natural gas from the grid and convert it to hydrogen and $\mathrm{CO} 2$. The hydrogen power plant will generate approximately $400 \mathrm{MW}$ of low-carbon electricity, and could provide more than 5 per cent of Abu Dhabi's current power generation, (United Arab Emirates State of Energy Report ,2015).

\section{SWOT analysis}

The SWOT analysis carried out to examine the current energy status of the UAE as well as its future energy mix and prospects is now reported.

\section{1) Strengths}

- The UAE government is committed to develop further renewable energy strategies.

- The UAE developed the legal frameworks, and based on legal frameworks the UAE has announced that it aims to produce 7 per cent of electricity from renewable sources by 2020 . The creation of Masdar, the UAE's multibillion dollar investment company, as well as such projects as Shams 1 solar project, Hydrogen Power Abu Dhabi (HPAD), MBM Solar Holding Inc., Dubai - Solar Power Plant, signals the Emirate's goal to lead in the clean-technology market.

- The infrastructure and industrial base in the UAE is developing.

- Many attractive locations are available for both solar and wind energy in the UAE.

- The UAE arguably exhibits the most political stability of any country in the region.

- The UAE one of the most encouraging investment and giving incentives to the private sector in the world. 
- The UAE government provides land for renewable energy.

- Several universities provide programs in engineering related to RE plus several research centers active in RE, especially Masdar.

- The UAE already has several successful pilot projects in place.

- The UAE provides adequate funding for research in RE.

- The UAE has expressed its commitment to the global carbon agenda and has plans to reduce its $\mathrm{CO} 2$ emissions by $30 \%$ by 2030 from the present.

- By exhibiting transparency, in part to avoid concerns about its use of nuclear technologies, the UAE sought and received International Atomic Energy Agency (IAEA) approval for its nuclear project, and committed itself to forgoing the domestic enrichment and reprocessing of nuclear fuel by signing a law that banned that practice within the country. In addition, the UAE signed a nuclear cooperation agreement with the United States in 2009, and is a signatory of the Nuclear Non-Proliferation Treaty.

- The legal system, e.g. the Federal Law Regarding the Peaceful Uses of Nuclear Energy, is established. It provides for the development of a system of licensing and control of nuclear material, as well as establishing the Federal Authority of Nuclear Regulation (FANR). FANR is an independent entity charged with overseeing the regulation of the whole of the UAE's nuclear energy sector as well as appointing the regulator's board.

\section{2) Opportunities}

- The UAE's adequate funding for RE can help advance RE technology.

- The investment climate in the UAE open and attractive.

- The UAE is a promising renewable energy market.

- There is strong government support for the RE industry

- There is a trend towards increased participation of the private sector in the UAE's energy sector.

- Much of Abu Dhabi's existing electricity and water production capacity was installed by private developers.

- The UAE has implemented an auction mechanism to support the deployment of large scale renewable energy projects.

- The UAE has significant potential for small-scale deployment in the solar rooftop market.

- The UAE has significant potential for replacement of out-of-date generators in off-grid settings.

\section{3) Weaknesses}

- The initial cost for RE is still high compared with conventional technology.

- The UAE may be considered a small market by the large investing RE companies.

- $\quad$ Some RE technologies are still nor deployed and are still expensive.

- Professional expertise needs more attention from the energy sector.

- There is a lack of awareness among the public and consumers about the impotence of RE.

- Electricity for households and agriculture still depends on fossil fuels.

- Results of applied research in RE are still not considered ready for commercialization.

\section{4) Threats}

- $\quad \mathrm{RE}$ is still perceived as uncertain and risky by local and foreign investors.

- Impact from the global energy market, e.g., in January 2016, the OPEC Reference Basket (ORB) reached its lowest level (\$22.48/barrel) since the price decline that started in the second half of 2014. It has since exhibited a general upward trend and over the past couple of months it has fluctuated in the range of $\$ 40-45 / \mathrm{bbl}$. On the supply side, nonOPEC production has contracted this year, while demand remains relatively heathy at around 1.2 million barrels per day.

- Volatility and challenges exist in the global behavior of oil stocks.

- Future predictions are often imprecise.

- Fossil fuel markets appear likely to continue to fluctuate, e.g. OPEC is predicted to provide an increasing share of global production, approaching 50 percent by 2040, a level not seen since the 1970 s, while unconventional production is predicted to more than double between 2015 and 2040.

\section{Conclusions}

Despite having some of the largest deposits of hydrocarbons in the world, the UAE is planning to diversify its energy mix beyond hydrocarbon-based electricity generation, including nuclear and renewable-energy technologies. This will likely help mitigate the future economic risks of being largely exposed to fossil fuel prices. Internally, energy waste and inefficiencies are some of the major challenges facing the UAE. Diversification of the energy mix of the UAE is needed to increase the low to moderate utilization of unconventional and renewable energy resources, but it comes with technical and policy challenges. The status quo of high income and low energy prices has created some inefficiencies, adding pressures on hydrocarbon resources and the environment. A general 
change in behavior would help drive the region's competitiveness and boost efficiencies in the longer term .[ 22].

The hydrocarbon sector is advanced and there are amny initiatives and technologies deployed to exploit the full of potential the oil fields and to enhance production further.

\section{References}

[1] BP Statistical Review of World Energy, June (2014), pg 30.

[2] Cherni, J., Kentish, J. (2007): Renewable energy policy and electricity market reforms in China. Energy Policy, 35:3616-3619.

[3] Dassisti M, Carnimeo L. (2012): Net modelling of energy mix among European countries: a proposal for ruling new scenarios. Energy 2012;39:100-11.

[4] Facts Global Energy, (2014): Gas Insights, January 30, 2014, Issue 207, pg 2.

[5] Federal Competitiveness and statistics Authority 2016. The 2016 report focuses on countries' ability to innovate in the digital economy $124 \mathrm{p}$.

[6] Foley AM, Gallachóir BP, Hur J, Baldick R, McKeogh EJ. (2010):A strategic review of electricity systems models. Energy 2010;35:452230.

[7] Iglinsk B., Buczkowski R., Cichosz M. (2015): Biogas production in Poland - current state, potential and perspectives. Renewable and Sustainable Energy Reviews, 50: 686-695.

[8] Lipp J. (2007): Lessons for effective renewable electricity policy from Denmark, Germany and the United Kingdom. Energy Policy 2007;25:5481-95.

[9] Lewis, J.J, Wier, R.H, (2007): Fostering a renewable energy technology industry: an international comparison of wind industry policy support mechanism. Energy Policy, 3067-3077.

[10] Mitchell C, Conner P, (2004), "Renewable energy policy in the UK, 1990-2003" Energy Policy 32 1887-1889.

[11] Middle East Economic Survey (2014): Abu Dhabi's Oil Production Capacity Target Slips," volume 57, issue 15 (April 11, 2014).

[12] Middle East Economic Survey, (2015): Service Firms Retrench Despite Record Mideast Takings," volume 58, issue 4 (January 23, 2015).

[13] Nadine Pahl , Anne Richter (2009): SWOT analysis. idea, methodology and a practical approach. GRIN Verlag 2009, $62 \mathrm{p}$

[14] Nimer Abu Ali (2012): Renewable energy review, United Arab Emirate. Renewable Energy World, Edition Dec. 2012.

[15] Suhail, Al-Mazrouei (UAE Energy Minister) (2015): Energy our access to renewable energy by $7 \%$ in 2030. 28 March 2015, Emirate Today.

[16] Thomas J. Chermack, and Benrnadette K.Kasshanna. (2007): The Use and Misuse of SWOT Analysis and Implications for HRD Professionals. Human Resource Development International, Vol. 10, No. 4, 383 - 399, December 2007

[17] Terrados, J. ; Almonacid, G. \& Hontoria, L. (2007). Regional energy planning through SWOT analysis and strategic planning tools: impact on renewable development. Renewable \& Sustainable Energy Reviews 11, pp. 1275-1287.

[18] United Arab Emirates (UAE) State of Energy Report, 2015, Published by Ministry of Energy, UAE p13.

[19] United Arab Emirates (UAE) State of Energy Report, 2015, Published by Ministry of Energy, UAE, p34-35.

[20] United Arab Emirates Oil industry (2008). Country Analysis Briefs. US Energy Information Administration. 2007. Retrieved 2008-04-27.

[21] US Energy Information Administration (2014): Annual energy outlook 2014 with projection to 2040.DOE/ EIA-0383. U.S. Energy Information Administration Office of Integrated and International Energy Analysis U.S. Department of Energy Washington, DC 20585, This publication is on the WEB at: www.eia.gov/forecasts/aeo.

[22] US Energy Information Administration (2013): Assumption to the annual energy outlook 2013. DOE/ EIA-0383. U.S. Energy Information Administration Office of Integrated and International

Energy Analysis U.S. Department of Energy Washington, DC 20585, This publication is on the WEB at: www.eia.gov/forecasts/aeo.

[23] US Energy Information Administration (2007): Assumption to the annual energy outlook 2007 with projection to 2030. DOE/ EIA-0383. U.S. Energy Information Administration Office of Integrated and International Energy Analysis U.S. Department of Energy Washington, DC 20585, This publication is on the WEB at: www.eia.gov/forecasts/aeo

About Author (s):

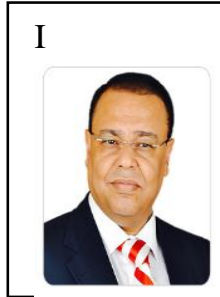

Professor Fares Howari Dean College of Natural \& Health Sciences and distinguished and highly professional in Environmental Sciences and Remote Sensing

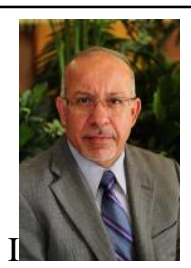

mage

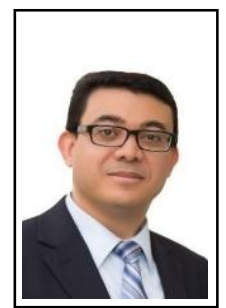

Prof.Yousef Nazzal, is a Professor and department chair, highly experiences and professional in environmental sciences.
Dr. Ahmad Yousef is a distinguished and highly accomplished professional of professional experience in Geographic Information Systems, Energy \& Water Resources. 